\title{
Expression of platelet activating factors and its receptor in cat uterus during early pregnancy
}

\author{
Ali Reha AĞAOĞLU ${ }^{1}$, Özgecan KORKMAZ AĞAOĞLU², Ercan KURAR ${ }^{3,4}$, Aydın GÜZELOĞLU ${ }^{3,4}$, \\ Seyit Ali KAYIŞ ${ }^{5}$, Mehmet Osman ATLI ${ }^{6}$, Sabine SCHAFER-SOMI ${ }^{7}$, Selim ASLAN ${ }^{8}$

\begin{abstract}
${ }^{1}$ Mehmet Akif Ersoy University, Faculty of Veterinary Medicine, Department of Obstetrics and Gynecology, Burdur, Turkey; ${ }^{2}$ Mehmet Akif Ersoy University, Faculty of Veterinary Medicine, Department of Animal Science, Burdur, Turkey; ${ }^{3}$ Selcuk Research and Application Center (ILTEK), Konya, Turkey; ${ }^{5}$ Selcuk University, Faculty of Agriculture, Department of Animal Gynecology, Diyarbakir, Turkey; ${ }^{7}$ Centre for Artificial Insemination and Embryo Transfer, University of Veterinary Medicine
\end{abstract} \\ University, Faculty of Veterinary Medicine, Department of Genetics, Konya, Turkey; ${ }^{4}$ Selcuk University, Advanced Technology \\ Science, Biometry-Genetics Unit, Konya, Turkey; ${ }^{6}$ Dicle University, Faculty of Veterinary Medicine, Department of Obstetrics and \\ Vienna, Austria; ${ }^{8}$ Ankara University, Faculty of Veterinary Medicine, Department of Obstetrics and Gynecology, Ankara, Turkey.
}

Summary: Platelet activating factors (PAF1 $\beta$, PAF1 $\gamma$, PAF:ah, PAF-R) have a significant role during mammalian pregnancy process. This study aimed to investigate expression profiles of PAF gene family in cat uterus during pregnancy. Tissue samples were collected via ovariohysterectomy at days $7(\mathrm{Gr} 1 ; \mathrm{n}=3), 18-20(\mathrm{Gr} 2 ; \mathrm{n}=7), 24-25(\mathrm{Gr} 3 ; \mathrm{n}=5)$ after mating from the different regions of the uterus. Relative expression levels of genes were quantified using real-time qRT-PCR. A mixed model was fitted on the normalized data and Least Significant Difference (LSD) test was employed to determine significant differences between groups. Expressions of PAF genes were assessed in the cat uterus during pregnancy around implantation period; however, no significant differences were detected between the preimplantation and the implantation stage. Similarly, no significant difference concerning mRNA expression was assessed between different parts of the uterus during pregnancy. In conclusion, PAF genes are expressed in the cat uterus during early pregnancy. However, this expression is not associated with changes in the uterus during early pregnancy.

Key words: PAF, cat, pregnancy, qRT-PCR.

\section{Kedi uterusunda, platelet aktive edici faktörler ve reseptörünün erken gebelik dönemindeki ekspresyonu}

Özet: Platelet aktive edici faktörler (PAF1 $\beta$, PAF1 $\gamma$, PAF:ah, PAF-R), memeli hayvanların gebelik sürecinde önemli bir role sahiptir. Bu çalışmanın amacı, gebelik süresince kedi uterusunda PAF gen ailesi ekspresyon profillerini araştırmaktır. Doku örnekleri çiftleşme sonrası $7(\mathrm{Gr} 1 ; \mathrm{n}=3), 18-20(\mathrm{Gr} 2 ; \mathrm{n}=7), 24-25$. (Gr3; n=5) günlerde yapılan ovariyohisterektomi operasyonları ile uterusun farklı bölgelerinden toplandı. Nispi mRNA ekspresyon seviyeleri real-time PZR kullanılarak tespit edildi. Normalize edilmiş veriler karışık model kullanılarak analiz edildi ve istatistikî olarak farklı olan gruplar Asgari Önemli Fark (AÖF) testi ile tespit edildi. Kedi uterusunda implantasyon sürecinde PAF genlerinin eksprese olduğu gözlenmiştir ancak; istatistikî olarak çalışma grupları ve uterus bölgeleri arasında herhangi bir fark bulunmamıştır. Sonuç olarak, kedilerde erken gebelik sürecinde uterusta PAF genleri eksprese olmaktadır. Ancak; bu ekspresyonların erken gebelik döneminde uterusta görülen değişikliklerle ilişsisi yoktur.

Anahtar sözcükler: PAF, kedi, gebelik, qRT-PZR

\section{Introduction}

Platelet activating factor (PAF) has a potential for biological and pathophysiological events (37) and is a mediator synthesized by platelets, neutrophils and macrophages, leading to platelet aggregation (14). However, it is also produced by a number of nonimmune cells such as endothelial (9), vascular, muscle (43), glomerular (13) and endometrial cells (4, 5, 7, 45). PAF plays a role in many reproductive events (16), including ovulation (1), fertilization (27), implantation and early development of embryo (28). PAF has been determined in the uterus of rats (45), rabbits (5), dogs (35) and humans (4). It plays a significant role in mammalian reproduction $(29,32)$. In peri-implantation period, PAF concentration increases significantly in the human uterus (4) and stimulates prostaglandin $\mathrm{E} 2\left(\mathrm{PGE}_{2}\right)$ production in fetal membranes of humans $(8,24)$. The PAF and PAF-R (receptor) synthesis is affected by the presence of steroids in the endometrium in humans (42). Endometrial PAF-R mRNA expression was significantly induced by estradiol and progesterone in sheep (11). After ovariectomy, concentration of PAF in the rat uterus was declined (25). PAF could regulate its own receptor in the endometrial cells. Addition of exogenous PAF in 
endometrial cell culture increased PAF-R expression in sheep (10). Stimulation by progesterone increased the concentration of PAF in the endometrium of ewe on days $10-16$ of the cycle (11).

Tiemann et al. (41) observed that PAF plays an important role in the control of the uterine neovascularization and modulation of the cell growth of the endometrium in preparation of implantation. The concentration of PAF is controlled by synthesis and degradation of PAF in the uterus. Degradation of PAF is governed by PAF acetylhydrolase (PAF:ah), which is the metabolic enzyme for PAF (38). PAF:ah activity is minimum in the uterus during the preimplantation phase of pregnancy in the mouse uterus (30). Implantation is a process between embryo and the endometrium and PAF plays an important role in cell interactions in the uterus during this process (44).

Biological effects of PAF are thought to be receptor (PAF-R) mediated (17). This receptor is present on various cell types, such as smooth muscles, neutrophils, monocytes (12) and also on endometrial cells (20). PAF$\mathrm{R}$ is mainly placed in the endometrial luminal and glandular epithelium in humans (3), rabbits (21), and heifers (40).

Investigations on local immunological interactions between fetus and endometrium could be helpful to develop nonsurgical contraceptive methods. A physiological effect of endometrial PAF has not been fully explained in felines. The hypothesis of the study is that the PAF gene family (PAF1 $\beta$, PAF1 $\gamma$, PAF:ah, PAF-R) has an important role in feline early and mid-gestation. The objective of this study was to investigate the expression profile of members of the PAF family in the pregnant feline uterus throughout gestation.

\section{Materials and Methods}

Animal Material and Experimental Procedure: Cats were ovariohysterectomized at days $7(\mathrm{Gr} 1 ; \mathrm{n}=3), 18-20$ (Gr2; n=7), 24-25 (Gr3; n=5) after mating, respectively. The preimplantation group (day 7) was proven pregnant by embryo flushing of the uterus after surgery. Uterine tissue was excised from the middle (md), apex (ap) and corpus (cp) of the horn from Gr1 (preimplantation) and placental (plc), interplacental (iplc) and corpus uteri (cp) from Gr2 and Gr3 (postimplantation). All tissue samples from the uterus were excised and snap frozen in liquid nitrogen after embedding in Tissue Tek O.C.T. Compound $\AA$ (Sanova Pharma GmgH, Vienna, Austria).

Total RNA Isolation: RNA isolation, quality control, genomic DNA removal by DNAse-I and cDNA synthesis procedures were conducted as described by Kurar et al. (22). Briefly, total RNA isolation was performed by using TRIzol Reagent (Invitrogen, Carlsbad, CA, USA) and approximately $50 \mathrm{mg}$ of uterine tissue. The RNA pellets in each tube were dissolved in $100 \mu \mathrm{l}$ of DEPC-treated sterile water. RNA quality was determined by loading $10 \mu \mathrm{l}$ of each RNA sample on $2 \%$ agarose gel and by measuring 260/280 ratio in NanoDrop ND-100 (Thermo Scientific, Wilmington, DE, USA). Two $\mu \mathrm{g}$ of RNA samples were first cleaned for possible genomic DNA contamination by DNAse-I digestion and then subjected to reverse transcriptase reaction for first strand complementary DNA (cDNA) synthesis using RevertAidTM FirstStandart cDNA Synthesis Kit (Fermentas, Glen Burnie, MD, USA) according to the manufacturer's instructions.

Primer Design and Real Time PCR: Primers for PAF gene family were derived from multispecies sequences by using the Primer3 program from NCBI (http://www.ncbi.nlm.nih.gov/) database. The primer pair sequences and product sizes are shown on Table 1.

qRT- PCR was used to evaluate the expression profiles of PAF gene families. The reaction was set up as follows: $12.5 \mu$ SYBR Green Master Mix (2X), $5 \mathrm{pMol}$ of each primer (Table 1), $1 \mu \mathrm{cDNA}$ and $\mathrm{dd}_{2} \mathrm{O}$ up to 25 $\mu \mathrm{l}$ of final volume. Thermal cyclic conditions were initial denaturation at $95^{\circ} \mathrm{C}$ for $10 \mathrm{~min}$ followed by 40 cycles of denaturation, annealing and extension $\left(95^{\circ} \mathrm{C} 30 \mathrm{sec}\right.$, $60^{\circ} \mathrm{C} 30 \mathrm{sec}, 72^{\circ} \mathrm{C} 30 \mathrm{sec}$ ) on an Applied Bioystems 7500 Real-Time PCR System (Applied Bioystems Foster City, CA, USA) at the Selcuk University Advanced Technology Research and Application Center (ILTEK). From the RNA extraction to the qRT- PCR, the whole procedure was performed twice as technical replicate. As housekeeping gene, glyceraldehyde-3-phosphate dehydrogenase (GAPDH) was selected according to Kayis et al. (18).

Statistical Analysis: Before statistical analysis, the efficiencies of amplification of target genes and internal

Table 1. Primers used in qRT-PCR analyses

Tablo 1. qRT-PZR analizlerinde kullanilan primerler

\begin{tabular}{|c|c|c|c|}
\hline \multirow{2}{*}{ Gene } & \multicolumn{2}{|c|}{ Primer Sequence (5'-3’) } & \multirow{2}{*}{$\begin{array}{c}\text { PCR } \\
\text { Product (bp) }\end{array}$} \\
\hline & Forward & Reverse & \\
\hline GAPDH & ATCACCATCTTCCAGGAGCGAGA & GTCTTCTGGGTGGCAGTGATGG & 341 \\
\hline PAF1 $\beta$ & GCCACAGGCCAAGATCATTGTGTT & AACCTTGAGGAGCTGGTTCACCTT & 100 \\
\hline PAF $1 \gamma$ & GTTCGTGGCCGACAGCAAAGATAA & GCTGTCACCACCAATGCCAAAGTT & 142 \\
\hline PAF:ah & TTTCTGCAAGCAGATCCCAGAGGA & GATGCACCTGGCAATTCCGAACAT & 125 \\
\hline PAF-R & TGGCATCTCTTTGTCCCTGGTCAT & TGCATGAGTAGCTTGCGGATGATG & 249 \\
\hline
\end{tabular}


control (GAPDH) were examined using real-time PCR amplification of serial dilutions (over a 256-fold range) of cDNA. Based on confirmation that the amplification efficiencies of the target and reference genes are nearly the same, data normalization process was performed according to Livak and Schmittengen (23) via $2^{-\Delta C_{T}^{\prime}}$ method, where $\Delta C_{T}^{\prime}=C_{T \text {, target }}-C_{T \text {, reference }}$ (where $C_{T \text {, target }}$ and $C_{T, \text { reference }}$ are threshold cycles for target and reference gene amplifications, respectively). Following normalization process, Anderson-Darling normality test was performed to obtain distributional properties of data. We performed $\log$ transformation on PAF1 $\beta$, PAF $1 \gamma$, and PAF:ah and square root transformation on PAF-R to stabilise variance. The following model was fit on the transformed data

$$
y_{i j k}=\mu+G_{i}+L_{j}+G L_{i j}+e_{i j k}
$$

with the effects defined as follows:

$y_{i j k}=$ transformed gene expression value for the tissue sample taken from $j^{\text {th }}$ region $(j=\mathrm{ap}, \mathrm{md}, \mathrm{cp}$, plc, iplc) of $k^{\text {th }}$ individual that take place in $i^{\text {th }}$ group ( $i=$ day 7, day 18-20, day 24-25);

$\mu=$ effect of the overall mean;

$G_{i}=$ fixed effect of the $i^{\text {th }}$ group;

$L_{j}=$ fixed effect of the $j^{\text {th }}$ region;

$G L_{i j}=$ group - region interaction;

$e_{i j k}=$ residual term for the tissue sample taken from $j^{\text {th }}$ region of $k^{\text {th }}$ individual that take place in $i^{\text {th }}$ group.

Least Significant Difference (LSD) test was applied to detect statistically significant group(s). All analyses were carried out using R 2.14.1 (31).

\section{Results}

Resulting qRT-PCR products were separated by electrophoresis on $2 \%$ agarose gels and visualized after ethidium bromide staining (Fig. 1). Expressions of PAF1 $\beta$, PAF1 $\gamma$, PAF-R and PAF:ah were detected in the cat uterus. Expression profiles with $95 \%$ confidence interval (95\% CI) of PAF genes during the preimplantation and postimplantation stage are illustrated in Fig. 2. The PAF1 $\gamma$ expression decreased in Gr3 but did not change significantly among the placental, interplacental sites and corpus uteri. Expression of PAF genes did not significantly differ between experimental days and among regions.

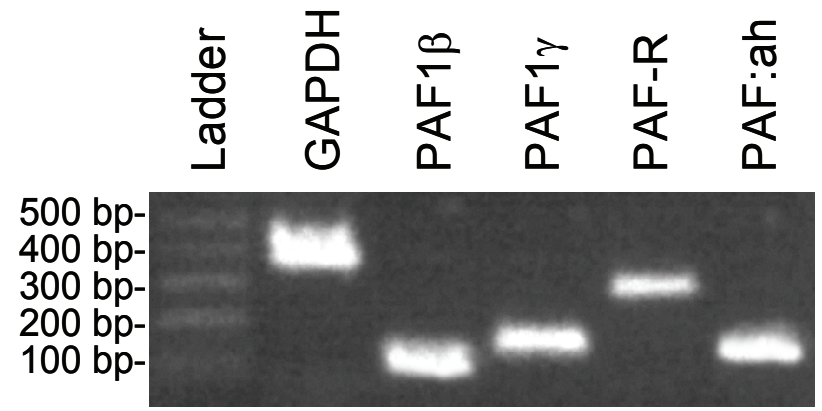

Fig 1. Expression of PAF genes at mRNA level

Şekil 1. PAF genlerinin mRNA düzeyinde ekspresyonları

\section{Discussion and Conclusion}

Successful implantation of blastocysts and gestation requires synergistic interactions between embryo and the uterus. These events are controlled by variety of mediators and factors such as growth factors, cytokines, hormones and enzymes $(6,34,35)$. Many of these factors are related to inflammation process. Implantation and inflammation process have several physiological events in common, including increased vascular permeability and some inflammatory mediator release. One of these factors is PAF. Spinks et al. (39), demonstrated that PAF inhibitor has preventive effect for implantation in mouse and rat (2). PAF induces contraction of the smooth muscle of the uterus. PAF was detected in amniotic fluid and PAF:ah decreased during late stage of pregnancy suggesting that PAF plays an important role in progress of gestation (19). Several parts of the reproductive tract and reproductive functions are affected by PAF. PAF affects the release of prostaglandin from endometrial tissue in ewes (33), humans (36), guinea pigs (26) and heifers (15). In the present study, PAF expression in the uterus of pregnant cats was detected between days 7 to 25 of pregnancy. PAF is released by ovine endometrial cells at days 10 and 16 of the sexual cycle. Stimulation of the endometrium by steroid hormones may induce both PAF production and PAF-R expression. Expression of PAF-R increased in the preimplantation period in heifers. These facts support the idea that PAF plays an important role in the implantation process (41).

The result of the current study showed the expression of PAF, PAF:ah and PAF-R within the endometrium during early pregnancy in the cat. PAF gene expression was observed in cat endometrium at days 7, 20 and 25. In contrast to other species, PAF gene expression did not increase significantly in the course of pregnancy. Additionally, the expression of genes was not different between groups and regions (d7, d20, d25). And the PAF1 $\gamma$ expression decreased in Gr3 but did not change significantly among the placental, interplacental sites and corpus uteri. It is known from previous studies in other species that PAF expression is under the control of progesterone. Since pregnant cats are expected to have high concentrations of circulating serum progesterone, a visible influence was expected. The expression of PAF may also be associated with sexual cycle stage and other steroid hormone levels. Further research is needed to evaluate expression profiles of these genes in nonpregnant cats together with the pregnant ones as in this study. Furthermore, the protein expression of fetal and uterine cells and the changes in the course of pregnancy should be investigated. 



Figure 2. Expression and 95\% confidence interval of PAF genes in feline uterus during the preimplantation and postimplantation periods.

Şekil 2. Kedi uterusunda PAF genlerinin, preimplantasyon ve postimplantasyon dönemlerindeki ekspresyonları ve \%95 güven aralıkları. 


\section{References}

1. Abisogun AO, Braquet P, Tsafriri A (1989): The involvement of platelet activating factor in ovulation. Science, 243, 381-383.

2. Acker G, Hecquet F, Etienne A, Braquet P, MenciaHuerta JM (1988): Role of platelet-activating factor $(P A F)$ in the ovoimplantation in the rat: effect of the specific PAF-acether antagonist, BN 52021. Prostaglandins 35, 233-241.

3. Ahmed A, Dearn S (1996): The role of platelet-activating factor and its receptor in endometrial receptivity. Adv Exp Med Biol 416, 277-290.

4. Alecozay AA, Casslen BG, Riehl RM, Deleon FD, Harper MJK, Silvia M, Nouchi TA, Hanahan DJ (1989): Platelet-activating factor in human luteal phase endometrium. Biol. Reprod. 41, 578-586.

5. Angle MJ, Jones MA, McManus LM, Pinckard RN, Harper MJK (1988): Platelet-activating factor in the rabbit uterus during early pregnancy. J. Reprod. Fertil. 83, 711-722.

6. Atlı MO, Güzeloğlu A, Kurar E, Kayıș SA, Aslan S, Semacan A, Çelik S (2012) Expression of Epidermal Growth Factor (EGF) and Heparin-Binding EGF (HBEGF) RNA in Mare Endometrium. Kafkas Univ Vet Fak Derg 18, 463-467.

7. Battye KM, Evans G, O'Neill C (1996): Ovine endometrium synthesizes and releases platelet-activating factor, which can cause the release of prostaglandin $F 2 \alpha$ by the uterus in situ. Biol Reprod 54, 355-63.

8. Billah MM, DiRenzo GC, Ban C, Truong CT, Hoffman DR, Anceschi MM, Bleasdale JE, Johnston JM (1985): Platelet-activating factor metabolism in human amnion and the responses of this tissue to extracellular plateletactivating factor. Prostaglandins, 30, 841-850.

9. Cabre F, Tost D, Suesa N, Gutierrez M, Ucedo P, Mauleon D, Carganico G (1993): Synthesis and release of plateletactivating factor and eicosanoids in human endothelial cells induced by different agonists. Agents Actions 38, 212-219.

10. Chami O, Megevand A, Ott T, Bazer F, O'Neill C (1999): Platelet-activating factor may as an endogenous pulse generatior for sheep of luteolytic PGF2alpha release. Am J Physiol 276, 783-792.

11. Chami O, Evans G, O'Neill C (2004): Components of a plateletactivating factor-signaling loop are assembled in the ovine endometrium late in the estrous cycle. Am J Physiol Endocrinol Metab 287, E233-E240.

12. Chao W, Olson MS (1993): Platelet-activating factor: receptors and signal transduction. Biochem J 292, 617629.

13. Chen WP, Chen A, Lin CY (1995): In vitro effects of interleukins on human mesangial cells: implications for glomerulonephritis. J Pathol 175, 327-337.

14. Greenberg SG, Clark KE (1999): Hemodynamic effects of platelet-activating factor in nonpregnant and pregnant sheep. Am J Physiol Integr Comp Physiol, 277, R996R1001.

15. Gross TS, Thatcher WW, O'Neill C, Danet-Desnoyers G (1990): Platelet-activating factor alters the dynamics of prostaglandin and protein synthesis by endometrial explants from pregnant and cyclic cows at day 17 following estrus. Theriogenology 34, 205-218.

16. Harper MJK (1989): Platelet-activating factor: a paracrine factor in pre-implantation stages of reproduction? Biol Reprod, 40, 907-913.

17. Honda Z, Nakamura M, Miki I, Minami M, Watanabe T, Seyama Y, Okado H, Toh H, Ito K, Miyamoto T (1991): Cloning by functional expression of plateletactivating factor receptor from guinea-pig lung. Nature, 349, 342-346.

18. Kayis SA, Atli MO, Kurar E, Bozkaya F, Aslan S, Semacan A, Guzeloglu A (2011): Rating of putative housekeeping genes for quantitative gene expression analysis in cyclic and early pregnant equine endometrium. Anim Reprod Sci 125, 124-132.

19. Kim BK, Ozaki H, Lee S-M, Karaki H (1995): Increased sensitivity of rat myometrium to the contractile effect of platelet activating factor before delivery. $\mathrm{Br} \mathrm{J}$ Pharmacol 115, 1211-1214.

20. Kudolo GB, Harper MJK (1990): Estimation of PlateletActivating Factor Receptors in the Endometrium of the Pregnant Rabbit: Regulation of Ligand Availability and Catabolism by Bovine Serum Albumin. Biol Reprod, 43, 368-377.

21. Kudolo GB, Kasamo M, Harper MJK (1991): Autoradiographic localization of platelet-activating factor $(P A F)$ binding sites in the rabbit endometrium during the periimplantation period. Tissue Res 265, 231-241.

22. Kurar E, Atli MO, Guzeloglu A, Ozsensoy Y, Semacan A (2010): Comparison of five different RNA isolation methods from equine endometrium for gene transcription analysis. Kafkas Univ Vet Fak Derg, 16, 851- 855.

23. Livak KJ, Schmittgen TD (2001): Analysis of relative gene expression data using real-time quantitative PCR and the method. Methods, 25, 402-408.

24. Morris C, Khan H, Sullivan MHF, ElderMG (1992): Effects of platelet-activating factor on prostaglandin E2 production by intact fetal membranes. Am J Obstet Gynecol 166, 1228-1231.

25. Nakayama R, Yasuda K, Okumura T, Saito K (1991): Effect of 17 beta-estradiol on PAF and prostaglandin levels in oophorectomized rat uterus. Biochim Biophys Acta 1085, 235-240.

26. Norman SJ, Poyser NL (1992): The effects of plateletactivating factor on the output of prostaglandins from the guinea-pig uterus. PLEFA 47, 285-289.

27. O'Neill C (1987): Embryo-derived platelet-activating factor: a preimplantation embryo mediator of maternal recognition of pregnancy. Domest Anim Endocrinol, 4, 907-914.

28. O'Neill C, Gidley-Baird AA, Pike IL and Saunders DM (1987): Use of a bioassay for embryo-derived plateletactivating factor as a means of assessing quality and pregnancy potential of human embryos. Fertil Steril, 47, 969-975.

29. O'Neill C (1997): Evidence for the requirement of autocrine growth factors for development of Mouse preimplantation embryos in vitro. Biol Reprod, 56, 229237.

30. O'Neill, C (1998): Autocrine mediators are required to act on the embryo by the 2-cell stage to promote normal 
development and survival of mouse preimplantation embryos in vitro. Biol. Reprod. 58, 1303-1309.

31. R Development Core Team (2011). $R$ : A language and environment for statistical computing. R Foundation for Statistical Computing, Vienna, Austria. ISBN 3-90005107-0, URL http://www.R-project.org.

32. Ryan JP, O'Neill C, Ammit AJ, Roberts CG (1992): Metabolic and developmental responses of preimplantation embryos to platelet activating factor. Reprod Fertil Dev, 4, 387-398.

33. Salamonsen LA (1991): Effect of platelet activating factor on prostaglandin release from ovine endometrial cells in culture. PLEFA 44, 67-70.

34. Schäfer-Somi S (2011): The pregnant canine uterus: molecular insights until placentation. Reprod Dom Anim 46, 62.

35. Schäfer-Somi S, Sabitzer S, Klein D, Reinbacher E, Kanca H, Beceriklisoy H, Aksoy O, Kucukaslan I, Macun H, Aslan S (2012) Vascular Endothelial (VEGF) and Epithelial Growth Factor (EGF) as Well as PlateletActivating Factor (PAF) and Receptors are Expressed in the Early Pregnant Canine Uterus. Reprod Domest Anim. 2012 Mar 28. doi: 10.1111/j.1439-0531.2012.02019.x. [Epub ahead of print]

36. Smith SK, Kelly RW (1988): Effect of platelet-activating factor on the release of PGF-2a by separated cells of human endometrium. J. Reprod. Fertil. 82, 271-6.

37. Snyder F, Lee T-C, Blank ML (1989): Platelet-activating factor and related ether lipid mediators. Biological activities, metabolism, and regulation. Ann New York Acad of Sci, 568, 35-43.

38. Snyder F (1995): Platelet-activating factor: the biosynthetic and catabolic enzymes. Biochem. J. 305, 689-705.

39. Spinks NR, Ryan JP, O'Neill C (1990): Antagonists of embryoderived platelet-activating factor act by inhibiting the ability of mouse embryo to implant. J Reprod Fertil $\mathbf{8 8}$, 241-248.
40. Tiemann U, Tomek W, Schneider F, Wollenhaupt K, Kanitz W, Becker F, Pohland R, Alm H (2001): Plateletactivating factor (PAF)-like activity, localization of PAF receptor (PAF-R) and PAF-acetylhydrolase (PAF-AH) activity in bovine endometrium at different stages of the estrous cycle and early pregnancy. Prost Lip Med, 65, 125-141.

41. Tiemann U, Viergutz T, Jonas L, Wollenhaupt K, Pohland R, Kanitz W (2001a): Fluorometric detection of platelet activating factor receptor in cultured oviductal epithelial and stromal cells and endometrial stromal cells from bovine at different stages of the oestrus cycle and early pregnancy. Domest Anim Endocrinol 20, 149-164.

42. Tiemann U (2008): The role of platelet-activating Factor in the Mammalian Female Reproductive Tract, Reprod Dom Anim, 43, 647-655.

43. Tomlinson PR, Croft K, Harris T, Stewart AG (1994): Platelet-activating factor biosynthesis in rat vascular smooth muscle cells. J. Vasc. Res. 31, 144-152.

44. Velasquez LA, Maisey K, Fernandez R, Valdes D, Cardenas H, Imarai M, Delgado J, Aguilera J, Croxatto HB (2001): PAF receptor and PAF acetylhydrolase expression in the endosalpinx of the human Fallopian tube: possible role of embryo-derived $P A F$ in the control of embryo transport to the uterus. Hum Reprod 16, 1583-1587.

45. Yasuda K, Satouchi K, Saito K (1986): Plateletactivating factor in normal rat uterus. Biochem. Biophys. Res. Com. 138, 1231-6.

Geliş tarihi: 04.05.2012 / Kabul tarihi: 28.06.2012

\author{
Address for correspondence: \\ Dr. Ali Reha A ̆̆aoğlu \\ Department of Obstetrics and Gynaecology \\ Faculty of Veterinary Medicine \\ Mehmet Akif Ersoy University, 15030, İstiklal Campus, \\ Burdur-Turkey \\ e-mail:rehaagaoglu@mehmetakif.edu.tr
}

